\title{
KEPUASAN KONSUMEN DI INDUSTRI SUVENIR DALAM PERSPEKTIF E-COMMERCE DAN KUALITAS LAYANAN
}

\section{CUSTOMER SATISFACTION IN THE SOUVENIR INDUSTRY IN PERSPECTIVE E- COMMERCE AND SERVICE QUALITY}

\section{Budi Prasetiyo1)}

1) Universitas Nasional Pasim, Jl. Dakota No.8A, Bandung, Jawa Barat 40175, Indonesia

\begin{tabular}{|c|c|}
\hline ARTICLE INFORMATION & A B S T R A C T \\
\hline $\begin{array}{l}\text { Article history: } \\
\text { Received: May, 09, 20 } \\
\text { Revised: November, 26, } 20 \\
\text { Accepted: February, 03, } 21\end{array}$ & $\begin{array}{l}\text { This research was conducted on XYZ Souvenir consumers. The purpose } \\
\text { of this research is to determine how much the contribution of the use of E- } \\
\text { commerce and Service Quality affects customer satisfaction both partially } \\
\text { and simultaneously on XYZ Souvenir. The research method that will be } \\
\text { used in this research is the verification method. In this research, the unit of } \\
\text { analysis is individuals, namely XYZ Souvenir consumers. The sample in } \\
\text { this study was } 134 \text { respondents. Systematic random sampling is a }\end{array}$ \\
\hline $\begin{array}{l}\text { Keywords: } \\
\text { E-commerce } \\
\text { Service Quality } \\
\text { Consumer Satisfaction }\end{array}$ & $\begin{array}{l}\text { sampling withrawal technique used in this study. The analysis method } \\
\text { uses path analysis, while also testing the validity and reliability of the } \\
\text { research instrument. Based on the results of the study indicate that there } \\
\text { is an effect both partially and simultaneously on exogenous variables (E- } \\
\text { commerce and Service Quality) on endogenous variables (customer } \\
\text { satisfaction). The implication of this research that XYZ Souvenir can make } \\
\text { various improvements a good site design (such as information on } \\
\text { goods/services that are complete and clear, there are promotions such as } \\
\text { giving discounts, and special offers, accepting proposals from consumers } \\
\text { payment features used, making online promotions) and adding product } \\
\text { variations. }\end{array}$ \\
\hline
\end{tabular}

*Corresponding Author

This is an open access article under the $\underline{\mathrm{CC}-\mathrm{BY}}$ license.

Budi Prasetyo

Email :

Nararitelclub@gmail.com

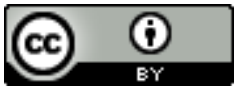

\section{INTRODUCTION}

A system is a unit of interconnected components with clear boundaries, working together to achieve certain goals. Information systems are everything that consists of humans, software, communication networks, hardware, communication networks, collaborated raw data so that it can provide useful information for companies/individuals. At present, information systems are one of the key advantages of a business strategy. Information is very important in supporting the continuity of company development. As a result, if there is a lack of information, within a certain time the company may experience a decrease in its ability to control resources, so it cannot make strategic decisions properly, which in turn can make the company unable to compete with its competitors.

In recent years the internet and web development have developed rapidly in the field of information and communication technology [1]. Massively developing information technology has made it possible for business people to more easily offer their merchandise and consumers find it easy to get the items they need. Besides, businesses and 
consumers can transact virtually safely and comfortably.

In addition to the development of information systems, rapid developments also occur in internet technology. This gives a significant influence on all aspects of our lives. The internet helps us to interact, communicate, trade with people from all corners of the world quickly and cheaply. In recent years the internet has encouraged many companies to offer a variety of products online. According to [2] E-commerce has been used extensively for advertising and informing about products. In particular, ecommerce supports business transactions, ordering goods, and payment via the internet.

The new world which is usually called the virtual world is the result of the development of the internet at this time. The virtual world provides opportunities for each individual to interact with other individuals without any physical limitations. In the era of globalization, this virtual world provides a significant contribution, especially in the business world. A high level of human activity at this time requires solutions in the provision of needs easily and quickly. For that, we need media that can connect consumers and producers. This media is known as the Internet. Through Ecommerce, all people have the same opportunities and opportunities to compete in business

E-commerce can be used as an alternative promising marketing strategy in this era. Ecommerce provides a lot of convenience in transactions, for example when sellers and buyers are separated by distance then E-commerce transactions can be done online. This means that the seller does not need to meet physically but enough in cyberspace. All companies that use ECommerce require analysis and evaluation of $e$ marketing and e-purchase opportunities. The biggest challenge is through an attractive website design that attracts consumers to make a repeat visit [3].

The object of research in this study is the company $X Y Z$ Souvenir. Companies engaged in retail and wholesale that sell various kinds of souvenirs using E-commerce. From the data of the number of transactions, the researcher found a phenomenon associated with a decrease in the number of people who transact on XYZ Souvenirs through E-commerce in 2019. For more details, can be seen in table 1.
Table.1 Number of Transaction XYZ Souvenir through E-commerce

\begin{tabular}{lr}
\hline Month & $\begin{array}{r}\text { Number of } \\
\text { Transaction }\end{array}$ \\
\hline January & 315 \\
February & 421 \\
March & 473 \\
April & 378 \\
May & 323 \\
June & 578 \\
July & 513 \\
August & 428 \\
September & 411 \\
October & 202 \\
\hline Souvenir (January-October 2019)
\end{tabular}

From Table.1, it can explain a phenomenon where 106 transactions are increasing from January to February, and there was an increase in transactions from May to June, which were 255 transactions but then declined In July 2019 there were 65 transactions and continued to decline transactions from August 2019 until there was a drastic decline in October. From this phenomenon, a development strategy is needed both from the aspect of service quality and Ecommerce available so that it can provide satisfaction to consumers. Besides, E-commerce and Service Quality can also be used by companies as a strategy to compete in the future.

With the increasingly competitive conditions between companies, each company is racing to expand the market. Direct market expansion expects to increase sales, so the company will have more customers. The company can increase its competitive advantage through excellent service when dealing with customers

For business people, E-commerce is expected to provide convenience for consumers when shopping so that it is expected to increase the level of satisfaction. XYZ Souvenir is one of the companies engaged in providing souvenir products. Souvenirs that are sold are intended to meet the needs of companies and individuals. Companies must be able to understand the behavior of their customers, especially on their wants and needs of consumers, especially on things that can give satisfaction to consumers. Recognizing the above, it appears that the importance of business understanding of the factors that affect customer satisfaction to achieve 
marketing success. In addition to providing benefits to consumers, the use of E-commerce also provides various benefits for companies. [4] E-commerce makes the company more effective because it can reduce costs and better understand consumers through direct communication.

The community as consumers do not just buy products without having consideration about the factors that can affect them in making decisions such as service quality. Service quality is a dynamic condition of the environment, services, products, processes, and personnel following the expectations of customers. [5, p. 107]. Perfect service quality can be achieved if consumers' expectations can be met by the services provided by the company.

The success of a company can be contributed to the quality of service that is part of the marketing strategy. The existence of a good quality of service will create satisfaction for its consumers. Truly satisfied consumers will repurchase and give recommendations to others.

Companies that are keen on seeing market competition, do not just focus on sales results and profit size. However, they also invest in the longterm goal of focusing on improving good service, providing competitive prices and attractive promotions so consumers can repurchase. Company management is required to be more careful in determining its competitive strategy and is expected to maintain and improve customer satisfaction so that customer loyalty can be created which is one of the goals of a company. Increasing competition, especially for businesses in the field of souvenirs, makes the company must be able to satisfy its customers by understanding the needs and desires of their customers. One aspect that must be considered is service through improving the quality of goods, creative designs, attractive designs, competitive prices, and display of goods. This is the best defense to face tough competition

Consumers are likened to a king who must be served, but this does not mean giving up everything to consumers. Efforts to satisfy the needs of consumers must be done profitably, where both parties feel happy and nothing is harmed. For marketing managers, customer satisfaction is very important because satisfied customers will spread positive stories following the experience received and will be a running advertisement for the company, and can reduce the cost of promotion, especially in attracting new customers. New consumers will be very interested when the information giver feels very satisfied with the services of the company so that new consumers are interested to immediately try and prove what the service is so impressive to consumers.

\section{RESEARCH METHOD}

The research method that will be used in this research is causal research. In this research, the unit of analysis is individuals, namely $\mathrm{XYZ}$ Souvenir consumers. The sample in this study was 134 respondents. In this research, the sampling technique was using convenience random sampling. The analysis method uses path analysis.

\subsection{Conceptual Framework}

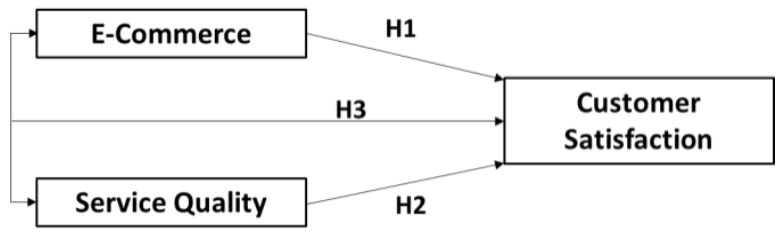

Fig 1.Conceptual Framework

In figure 1, it can be explained that it will be examined how much effect E-Commerce and Service Quality have on Customer satisfaction both partially and simultaneously.

\subsection{Research Hypothesis}

Based on business phenomena that occur at $X Y Z$ Souvenir where there has been a trend of a decrease in the number of online sales transactions during 2019. This decline reflects the lower consumer satisfaction of $\mathrm{XYZ}$ Souvenir. From this phenomenon, the research problem is obtained, which are things that can increase online sales transactions from $X Y Z$ Souvenir. A development strategy is needed both from the aspect of service quality and E-commerce available so that it can provide satisfaction to consumers

Service quality is a dynamic condition of the environment, services, products, processes, and personnel following the expectations of customers. [5, p. 107]. Perfect service quality can be achieved if consumers' expectations can be met by the services provided by the company. Besides service quality, e-commerce is one of the factors that can affect consumer satisfaction. Ecommerce provides a lot of convenience in 
transactions. E-commerce contributes significantly to influencing Customer Satisfaction [12].

Research problems then there are several research questions present namely:

1. Can E-commerce affect the increase in $X Y Z$ Souvenir Consumer Satisfaction?

2. Can Service Quality affect the increase in XYZ Souvenir Consumer Satisfaction?

3. Can E-commerce and Service Quality affect the increase in XYZ Souvenir Consumer Satisfaction?

The research questions above develop the following three research hypotheses:

$\mathrm{H} 1$ : There is an effect of E-commerce on XYZ Souvenir Consumer Satisfaction.

$\mathrm{H} 2$ : There is an effect between Service Quality on $X Y Z$ Souvenir Consumer Satisfaction.

H3: There is an effect between E-commerce and Service Quality on XYZ Souvenir Customer Satisfaction

\subsection{Data Types and Sources}

This quantitative study using two data sources, namely primary data and secondary data. Data from the questionnaire distributed to respondents were included in the primary data source. While data from companies, books, and research journals are part of secondary data sources.

\subsection{Identification and Operational Definition of Research Variables}

Table. 2 Variable Operations

\begin{tabular}{lll}
\hline \multicolumn{1}{c}{ Variable } & \multicolumn{1}{c}{ Indicators } \\
\hline E-commerce & 1. Transactions \\
$(\mathrm{XI})$ & 2. Marketing & \\
& 3. Electronic Systems & \\
Service Quality & 1. Reliability \\
(X2) & 2. Responsiveness & \\
& 3. Guarantee \\
& 4. Empathy & \\
Customer & 5. Physical Proof \\
Satisfaction (Y) & 1. Factors related to \\
& services \\
& 2. Factors related to \\
& service & \\
& 3. Factors related to \\
& purchasing & \\
\hline
\end{tabular}

From table 2, it can be explained that there are 3 variables studied, namely E-commerce, Service Quality, and Customer Satisfaction. The first exogenous variable to be examined in this study is E-commerce. E-commerce is an electronic system that allows selling, buying, and marketing activities on goods/services. E-commerce can be done through computer networks, the internet, radio, and television. [6, p. 33] From the above understanding, the dimensions of E-commerce are transactions, marketing of goods, and electronic systems. A description of the previous E-commerce in line with [7] argues that Ecommerce is an easy tool in getting goods and services via the internet. This allows it to be done in real-time, ordering goods/services online, transactions between businesses, etc.

The second exogenous variables that will be examined in this study is service quality. In marketing management strategy, service quality is an important thing that must be considered by marketers. For a company to survive and develop, the company must get the trust of customers. Quality of service is one of the important things in building company trust. Service quality is a dynamic condition of the environment, services, products, processes, and personnel following the expectations of customers [5, p. 107].

According to $[5$, p. 198] there are five main dimensions in service quality, including the following: (1) Reliability. This is related to the level of ability of the services provided by the company to consumers in terms of accuracy and timeliness when serving. The accuracy aspect looks at how the service provided is without error, while the timeliness shows how the service is provided under the initial agreement. (2) Responsiveness. This is related to the level of willingness and ability of personnel to help customers, respond to their desires, provide information related to the services to be provided, and how services can be delivered quickly. (3) Assurance. This is related to how employee behavior can foster customer confidence in the company and the creation of a sense of security felt by customers. This guarantee can also be interpreted that employees who always provide service politely, have good knowledge, and have the skills needed to handle any problems and questions from customers can increase customer confidence in the company. (4) Empathy. This is related to how the company can understand the problems of its customers, act in the interests of its customers, pay personal attention to its customers, and have adequate operating hours. (5) Tangible. This is related to the attractiveness of physical facilities provided, complete equipment, clean materials used by the company, and the neat appearance of its 
employees. Based on the five dimensions of service quality, customer satisfaction can be measured, understood, and used as a good outcome for the benefit of improving the quality of services provided to consumers, both first-time consumers and consumers who have repeatedly used the

According to $[8$, p. 138] Satisfaction is a feeling of pleasure or disappointment from someone who is the result of a comparison of the expected performance with received. If the performance is far from expectations, this will make consumers disappointed. Meanwhile, if the performance provided is as expected, consumers will be very happy or very satisfied. From this definition, it can be said that satisfaction is a feeling like someone's pleasure or disappointment with the product offered with the expected expectations.

Assessment of the good or bad quality of the services provided is a very thing that affects the satisfaction or dissatisfaction of consumers who feel it. Between service quality and satisfaction are closely related even though both have different understandings and concepts. When satisfaction compares consumer perceptions of what consumers normally expect, service quality compares perceptions of what consumers expect from companies delivering high-quality service.

Service quality is a dynamic condition of the environment, services, products, processes, and personnel following the expectations of customers. This approach confirms that quality does not only emphasize the aspect of the result, namely products and services but also concerns the quality of human beings and the quality of the environment. It is very difficult to realize if the company wants to make a quality product but without the support of qualified personnel and a good process. From the statement above regarding satisfaction is the comparison between consumer expectations and performance, the dimensions for consumer satisfaction are factors related to services, factors related to service, and factors related to purchasing.

The endogenous variables that will be examined in this study is consumer satisfaction. According to [5, p. 313], one of the most likely agreed-upon relationships is that satisfaction will change their perception of service quality for the better. The following rationale about the relationship between service quality and customer satisfaction, among others: (1) If the consumer has no prior experience with a company, then his perception of the quality of the company's services will be based on his expectations. (2) Subsequent interaction with the company will cause consumers to enter the disconfirmation process and revise their perceptions of service quality. (3) Any additional interactions with the company will strengthen or vice versa change the customer's perception of service quality. (4) The perception of service quality that has been revised modifies consumer buying interest for changes in the future. According to [9], 3 elements can be explained from satisfaction: customer satisfaction is an emotional response, a response to expectations on several things, and a response after the product has been enjoyed.

The relationship between service quality and consumer satisfaction according to [5, p. 118], service quality can be explained as an effort to meet the needs and desires of its customers and provide services following customer expectations, and have happy feelings and then compare between expectations and what is felt. The relationship between the applications of Ecommerce with consumer satisfaction is explained by research [10], [11], and [12].

\subsection{Test the validity and Reliability of Variable Instruments}

\section{a. Validity test}

This test is to find out whether the questions in the research instrument have measured what will be measured. In this test, to get a valid conclusion or not by comparing $r$ arithmetic and $r$ tables. If $r$ arithmetic > from $r$ table then questions in the instrument are considered valid. Besides by comparing $r$ arithmetic and $r$ table, conclusions can be drawn by looking at the significant value of $r$ arithmetic, if $<0.05$, it can be concluded that the questions in the research instrument are considered valid. [13, p. 174].

It is seen that each question item in the instrument has a value of $r$ count $>r$ table thus the question items on the variables $\mathrm{X} 1$ (E-commerce), $\mathrm{X} 2$ (Service Quality), and Y (Customer Satisfaction) are declared valid. This means that this research can continue its calculations and analysis because the research questionnaire has been declared valid.

b. Reliability test

A reliability test is done to see the stability and consistency of the measuring instrument. The test used in this study is based on the Cronbach Alpha value. 
Table 3 Reliability Test Results

\begin{tabular}{ccc}
\hline Variable & $\begin{array}{c}\text { Cronbach } \\
\text { Alpha value }\end{array}$ & Explanation \\
\hline $\begin{array}{c}\text { E-commerce } \\
(\mathrm{X} 1)\end{array}$ & 0,759 & Good \\
$\begin{array}{c}\text { Service Quality } \\
(\mathrm{X} 2)\end{array}$ & 0,887 & Good \\
$\begin{array}{c}\text { Customer } \\
\text { Satisfaction }(\mathrm{Y})\end{array}$ & 0,826 & Good \\
\hline
\end{tabular}

In table 3 it can be explained that all Cronbach Alpha values have exceeded 0.7 so that the questionnaire is considered consistent.

\section{RESULT AND DISCUSSION}

\subsection{RESULT}

Method Path analysis is carried out using SPSS. The output results are presented in the following table:

Table 4 Output Coefficients Results

\begin{tabular}{cccc}
\hline Model & $\mathbf{R}$ & $\begin{array}{c}\mathbf{R} \\
\text { Square }\end{array}$ & $\begin{array}{c}\text { Adjusted } \mathbf{R} \\
\text { Square }\end{array}$ \\
\hline 1 & $0,629^{a}$ & 0,396 & 0,387
\end{tabular}

In table 4, it can be explained the effect of the exogenous variables on the endogenous variables of the $\mathrm{R}$ Square number.

Table 5 Output Correlation Results

\begin{tabular}{|c|c|c|c|}
\hline \multicolumn{4}{|c|}{ Correlations } \\
\hline \multirow{4}{*}{$\begin{array}{l}\text { E- } \\
\text { commerce }\end{array}$} & & $\begin{array}{c}\mathrm{E}- \\
\text { commerce }\end{array}$ & $\begin{array}{l}\text { Service } \\
\text { Quality }\end{array}$ \\
\hline & $\begin{array}{l}\text { Pearson } \\
\text { Correlation }\end{array}$ & 1 & ,652 \\
\hline & & & ,000 \\
\hline & $\mathrm{N}$ & 134 & 134 \\
\hline \multirow{3}{*}{$\begin{array}{l}\text { Service } \\
\text { Quality }\end{array}$} & Pearson & ,652* & 1 \\
\hline & $\begin{array}{l}\text { Sig. }(2- \\
\text { tailed) }\end{array}$ & ,000 & \\
\hline & $\mathrm{N}$ & 134 & 134 \\
\hline
\end{tabular}

${ }^{* *}$. Correlation is significant at the 0.01 level (2tailed).

In table 5 , it can be seen that the correlation number between the exogenous variables is then used when calculating the influence of the exogenous variables on the endogenous variables using the path analysis approach.

Table 6 Model Summary Results

\begin{tabular}{cccc}
\hline & $\begin{array}{c}\text { Standardized } \\
\text { Coefficients } \\
\text { Beta }\end{array}$ & t value & Sign \\
\hline $\begin{array}{c}\mathrm{E}- \\
\begin{array}{c}\text { commerce } \\
\text { Service } \\
\text { Quality }\end{array}\end{array}$ & 0.358 & 4.003 & 0.00 \\
\hline
\end{tabular}

a Predictors: (Constant), Service Quality, Ecommerce

In Table 6, it can be seen that the value of the beta standardized coefficients number as the number of path coefficients. The $t$ value is used as a reference in testing hypotheses related to the partial effect of the exogenous variables on the endogenous variable.

Table 7 ANOVA Output Results

\begin{tabular}{ccc}
\hline Model & $\mathbf{F}$ & Sig. \\
\hline 1 & 42.953 & $0,000^{\mathrm{b}}$ \\
\hline
\end{tabular}

a Dependent variables: Customer Satisfaction

b. Predictors (Constant): Service Quality, Ecommerce

In table 7 , the $F$ value is used as a reference in testing the hypothesis related to the simultaneous effect of the exogenous variables on the endogenous variables.

\subsection{DISCUSSION}

a. Effect of E-commerce on Customer Satisfaction $X Y Z$ Souvenir

The amount of effect of E-commerce on Customer Satisfaction XYZ Souvenir can be determined through the following calculation:

Direct effect $=\left(p \_y x 1\right) \cdot\left(p \_y x 1\right)$

$=0.358 \times 0.358$

$=0.1281$

Indirect effect $=\left(p \_y x 1\right) \cdot\left(r \_x 1 x 2\right) \cdot\left(p \_y x 2\right)$

$=0.358 \times 0.652 \times 0.334$

$=0.07796$

Total effect $=0.1281+0.07796$

$$
=0.20606
$$

Based on the calculation above, it can be seen that the effect of the E-commerce variable on Customer Satisfaction XYZ Souvenir directly is 0.1281 , while indirectly (correlative through $\mathrm{X} 2$ ) is 
0.07796 and the total effect can affect changes in Customer Satisfaction is equal to 0.20606 or $20.60 \%$.

To test the hypothesis "E-commerce affects the Customer Satisfaction XYZ Souvenir". Based on the $t$ value number (E-commerce section) in table 6 , where the $t$ value is 4.003 with sign. 0.00 . The significance value $<0.05$ can explain that $\mathrm{E}$ commerce contributes significantly to influencing Customer Satisfaction and this supports the statement made by [12] where E-commerce affects Customers Satisfaction.

Based on the above discussion, it is necessary to change the XYZ Souvenir management policy related to E-commerce. Based on research from [14] that E-commerce must be able to provide convenience and be able to interact more actively with consumers. Besides according to [15], Ecommerce should have a good site design such as information on goods/services that are complete and clear, there are promotions such as giving discounts, and special offers, accepting proposals from consumers.

\section{b. Effect of Service Quality on Customer Satisfaction XYZ Souvenir}

To determine how much the contribution of service quality in influencing Customer Satisfaction $X Y Z$ Souvenir can be known through the calculation as follows:

$$
\begin{aligned}
\text { Direct effect } & =\left(p \_y x 2\right) \cdot\left(p \_y x 2\right) \\
& =0.334 \times 0.334 \\
& =0,3516
\end{aligned}
$$

Indirect effect $=\left(p \_y \times 2\right) \cdot\left(r \_x 1 \times 2\right) \cdot\left(p \_y x 1\right)$

$$
\begin{aligned}
& =0.334 \times 0.653 \times 0.358 \\
& =0.07796
\end{aligned}
$$

Total effect $\quad=0.1116+0.07796$

$$
=0.1895
$$

Based on the calculation above, it can be seen that the effect of the variable Service Quality on Customer Satisfaction $\mathrm{XYZ}$ Souvenir directly is 0.3516 , while indirectly (correlative through $\mathrm{X} 2$ ) is 0.07796 and the total effect can affect changes in Customer Satisfaction is 0,1895 or $18.95 \%$.

To test the hypothesis "Service Quality affects the Customer Satisfaction XYZ Souvenir". Based on the $t$ value (Service Quality section) of table 6, where the $t$ value is 3.733 with a significance of 0.00 . The significance value $<0.05$ so that it can be concluded that the Service Quality variable has a significant effect on Customer Satisfaction so that it supports the research proposed by [10], [11] and [12], it is said that Service Quality affects Customer Satisfaction

Based on the above discussion, it is necessary to change the XYZ Souvenir management policy related to Service Quality. Based on the opinion of [14], [15] that Service Quality can be improved by understanding customer needs through adding product variations.

c. The Effect of E-commerce and Service Quality on XYZ Souvenir Customer Satisfaction

To find out how much the percentage of the effect of E-commerce and Service Quality on Customer Satisfaction can be seen from the results of SPSS data processing in table 7. From table 7, it can be seen the effect of the two variables $X 1$ and $X 2$ on $\mathrm{Y}$ in the $\mathrm{R}$ Square value column is 0.396 then the other effect outside the model is $0.604(1-0,396)$.

$\mathrm{F}$ test was conducted to test the hypothesis of whether there is an effect of E-commerce (X1) and Service Quality (X2) variables on Customer Satisfaction $(Y)$ simultaneously. Based on the calculated $F$ value in table 6 , amounting to 42.953 with a significance of 0.00 (less than 0.05 ), it can be interpreted that there is a simultaneous effect between the E-commerce and Service Quality variables on Customer Satisfaction. This is supported by the results of research [14] that there is an effect of E-commerce and Service Quality together on Customer Satisfaction.

\section{CONCLUSION}

Based on the results of the research and discussion in the previous section, the following conclusions can be drawn:

1) The first hypothesis that reads E-commerce affects Customer Satisfaction $X Y Z$ Souvenir is proven true. The effect is $20.60 \%$. it is necessary to change the $X Y Z$ Souvenir management policy related to E-commerce. The company should create E-commerce that more convenient, interactive a good-looking site design with complete and clear information, more promotions (such as giving discounts and special offers), and accepting a request from consumers.

2) The second hypothesis which says Service Quality affects Customer Satisfaction XYZ Souvenir is proven true. The effect is $18.95 \%$., it is necessary to change the $X Y Z$ Souvenir management policy related to Service Quality. The company should improve service quality by adding product variations. 
3) The third hypothesis which reads E-commerce and Service Quality affects the purchasing decision of $X Y Z$ Souvenir is proven true. The simultaneous effect is $39.6 \%$.

\section{Managerial implication}

Based on the findings in this study, companies can make policies related to customer satisfaction from the aspects of E-Commerce and Service Quality. The policies that can be taken by companies include: E-Commerce can be reviewed both from its appearance and the clarity of the information provided. Promotion is carried out more intensely through E-Commerce in the form of discounted prices and special offers. Management of suggestions and information from customers can be done through E-Commerce. Besides, product development is needed continuously so that consumers can meet consumer needs.

\section{REFERENCES}

[1] M. I. Eid, "Determinants of E-Commerce Customer Satisfaction, Trust, and Loyalty In Saudi Arabia," Journal of Electronic Commerce Research, pp. 78-93, 2011.

[2] C. C. Lin, "A Critical Appraisal of Customer Satisfaction and E-commerce," Managerial Auditing Journal, pp. 2002-2012, 2003.

[3] K. Norizan dan N. A. Abdullah, "The effect of perceived quality dimensions on customer satisfaction, trust, and loyalty in e-commerce setting: A cultural analysis," Asia Pacific Journal of Marketing and Logistics, pp. 351371, 2010.

[4] J. Lu, "Model for Evaluating E-Commerce Based on Cost/Benefit and Customer Satisfaction," Information Systems Frontiers, pp. 265-277, 2003.

[5] F. Tjiptono, Strategi Pemasaran, Yogyakarta: AndiOffset, 2011.

[6] J. Wong, Internet Marketing for Beginners, Jakarta: Elex Media Komputindo, 2010.
[7] S. Kumar dan P. Petersen, "Impact of ecommerce in lowering operational cost raising customer satisfaction," Journal of Manufacturing Technology Management, pp. 283-302, 2006.

[8] P. Kotler dan K. L. Keller, Manajemen Pemasaran, Jakarta: Erlangga, 2009.

[9] A. A. Jahanshadi, M. A. H. Gashti, S. A. Mirdamadi, K. Nawaser dan S. M. S. Khaksar, "Study the effects of customer service and product Quality on Customer and Loyalty," International Journal of Humanities and Social Science, pp. 253260, 2011.

[10] H.-F. Lin, "The Impact of Website Quality Dimensions on Customer Satisfaction in the B2C E-commerce Context," Total Quality Management, pp. 363-378, 2007.

[11] A. A. Jahanshahi, M. A. H. Gasthi, S. A. Mirdamadi dan K. Nawaser, "Study the effect of Customer Service and product quality on Customer Satisfaction and Loyalty," International Journal of Humanities and Social Science, pp. 254-260, 2011.

[12] F. Anggraini dan P. Lestari, "Pengaruh Web E-Commerce, kualitas produk dan kualitas layanan terhadap kepuasan konsumen," Sosio e-kons, pp. 87-95, 2018.

[13] B. Simamora, Panduan Riset Perilaku Konsumen, Jakarta: PT Gramedia Pustaka Utama, 2004, p. 174.

[14] G. M. Disastra dan A. Wulandari, "Analisis Pengaruh Penerapan E-Commerce dan Kualitas Pelayanan terhadap Kepuasan Konsumen," Banking \& Management Review, pp. 740-750, 2016.

[15] A. Saputra dan C. Wongsosudono, "Analisis Pengaruh Penerapan E-commerce dan Kualitas Pelayanan terhadap Kepuasan Konsumen," Jurnal Manajemen Bisnis STIE IBBI, vol. 27, pp. 53-62, 2017. 


\section{Author Biography}

\section{Budi Prasetiyo}

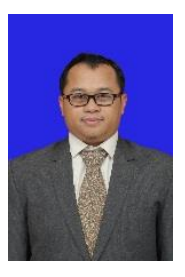

Budi Prasetiyo, born on September 12, 1980, in Bandung. He completed his undergraduate and postgraduate studies in Bandung. Currently registered as a lecturer at Universitas

Nasional Pasim specializing in

Marketing Management especially retail management. Aside from being a lecturer in tertiary institutions, he is also active as a cooperative facilitator in Lembaga Pendidikan Perkoperasian Nasional (Lapenkopnas) specializing in consumer cooperatives. 